\title{
種々のビニルモノマーの可溶化コラーゲンフィルムへの無触媒 光グラフト重合とグラフトフィルムの物性
}

\author{
原田 修*1 ・角田 和成*1 ・山本 統平*2
}

（受付 1998 年 12 月 21 日・蕃查終了 1999 年 2 月 8 日）

\begin{abstract}
要 旨 可溶化コラーゲンフィルムに種々の溶媒中でメタクリル酸メチル (MMA) の無触媒光グ ラフト重合を行った結果著しい溶媒効果が認められ、コラーゲンに対する膨潤能の高いメタノール> エタノール>プロパノール>アセトンニトルェンの順にグラフト率が高い傾向であった。 メタノール を溶媒にして MMA, メタクリル酸n-ブチル (BMA), メタクリル酸 2-ヒドロキシエチル (HEMA), ポリスチレン (PSt), および酢酸ビニル (VAc) をグラフト重合すると, VAc を除いて高グラフト率の フィルムが得られた. グラフトフィルムの DSC 測定, 動的粘弾性挙動, およびグラフトフィルムから 酸でコラーゲンを除去したグラフトポリマーのSEM 写真から, MMA, BMA, HEMA グラフトフィル ムではポリマーがコラーゲンフィルムに細かく分散した構造であることが示唆された。 いずれのグラ フトフィルムでも, 高グラフト率にもかかわらず片表面の約 $0.4 \mu \mathrm{m}$ 以上の厚さでコラーゲンが保持 されており，湿潤強度も大幅に向上できたことから十分医用材料としての使用が可能であると考えら れた。
\end{abstract}

\section{1 緒言}

筆者らは, 無触媒光グラフト重合法により可溶化コ ラーゲン（以下コラーゲンとする）フィルムにポリメ夕 クリル酸メチル (PMMA) を効率よくグラフト化できる ことりおよび PMMA グラフトフィルムの構造を明らか にした2). そして, PMMAグラフトフィルムの片表面 には少なくとも樑さ約 $0.4 \mu \mathrm{m}$ 以上の元のコラーゲン層 があり, さらに湿潤強度が向上することから生体適合性 のインプラント材料表面への応用が可能であることを示 唆した。

PMMA グラフトフィルムは, PMMAがコラーゲン フィルム内に杭を打ったような三次元網目 (IPN) 構造 をしている2!. 古くからゼラチンやコラーゲンと合成高 分子とのブレンドやIPN の研究が行われており ${ }^{3) ~ 99, ~}$ その物性は用いるモ/マーや合成高分子により大きな違 いが見られるが，片面にコラーゲン層を保持した不均一 のフィルムについての研究は見あたらない.

本研究では, 種々のモノマー, 溶媒を用いてコラーゲ ンフィルム表面にグラフト重合を行い, グラフト重合に 及ぼすモノマー，溶媒の影響，およびグラフトフィルム の物性について検討した。

*! 兵庫県立工業技術センター皮革工業指導所（\$670-0811 姫 路市野里字東河原 3)

*2 兵庫県立姫路工業大学工学部（区671-2201 姫路市書写 2167)

\section{2 実験}

\section{1 試薬および試料}

コラーゲンフィルムは既報”に従い調製した. ナカラ イテスク(株) より購入した試薬特級のメタクリル酸メ チル (MMA), スチレン (St), メタクリル酸 2-ヒドロキ シェチル (HEMA), メタクリル酸 $n$-ブチル (BMA), 酢酸ビニル (VAc) は常法により精製した後に, メ夕 ノール, エタノール, n-プロパノール, アセトン, トル エンはモレキュラーシーブ $3 \mathrm{~A}$ で脱水した後に用いた。

\section{2 無触媒光グラフト重合}

無触媒光グラフト重合はモノマーに MMA, St, HEMA, BMA, VAc, 溶媒にメ夕ノール, エタノール, プロパノール，アセトン，トルエンを用いて，既報1に 従い行った，照射後, ポリメタクリル酸メチル (PMMA), ポリメタクリル酸 $n$-ブチル (PBMA) グラフ トフィルムはアセトンで, ポリメタクリル酸 2-ヒドロ キシェチル (PHEMA) グラフトフィルムはエ夕ノール で, ポリスチレン (PSt) グラフトフィルムはテトラヒド ロフラン (THF) で 24 時間ホモポリマーを抽出して真 空乾燥した後, コラーゲンフィルムとグラフトフィルム の重量差からグラフト率を求めた。ここで，グラフト フィルムのモノマーに接していない面を $\mathrm{A}$ 面，モ， マーに接している面をB面とする。

2.3 溶媒中でのコラーゲンフィルムの膨潤

コラーゲンフィルムを室温でメタノール, エタノー 
原田・角田・山本

Table 1. Initiator-free photo-graft polymerization of MMA and the swelling ratio of solubilized collagen films in various solvents ${ }^{\mathrm{a}}$

\begin{tabular}{lccc}
\hline \hline Solvent & $\begin{array}{c}\text { Swelling ratio } \\
(\mathrm{wt} \%)\end{array}$ & $\begin{array}{c}\text { Grafting } \\
(\mathrm{wt} \%)\end{array}$ & $\begin{array}{c}\text { Yield of homopolymer } \\
(\mathrm{wt} \%)\end{array}$ \\
\hline MeOH & 52 & 400 & 8 \\
EtOH & 31 & 261 & 7 \\
$n$-PrOH & 3 & 19 & 8 \\
Acetone & 0 & 4 & 12 \\
Toluene & 0 & 8 & 10 \\
MMA (bulk) & 1 & 7 & 11 \\
\hline
\end{tabular}

a) Solubilized collagen films, $40 \sim 50 \mathrm{mg}$. Solution, $5.5 \mathrm{~mL}$. Irr. time, $3 \mathrm{~h}$. Temp., $20^{\circ} \mathrm{C}$. [MMA], $0.943 \mathrm{M}$. Swelling ratio was estimated from the weight before and after penetration into solvent for $30 \mathrm{~min}$ at room temperature.

ル, プロパノール, アセトン,トルェン, MMAに20 分間浸漬し、浸清前後の重量変化から膨潤率を算出し た.

\subsection{FT-IR-ATR スペクトル}

FT-IR-ATRスペクトルは, バイオラッドラボラト リーズ社製赤外分光装置 (FTS-40) を用いて測定した.

クリスタルには Ge, KRS-5 用い, 入射角 $45^{\circ}$, 分解能 $4 \mathrm{~cm}$ 'で 200 回積算した. Geの $1580 \mathrm{~cm}{ }^{\prime}$ (PStのべ ンゼン環に基づく吸収), $1725 \mathrm{~cm}{ }^{1}$ (PMMA, PBMA, PHEMA のエステルの吸収) での浸み込み深さは約 0.4 $\mu \mathrm{m}$ である。

\section{5 動的粘弾性測定}

前報)に従いグラフトフィルムの動的粘弾性測定を行 い, 温度・周波数依存性からグラフトポリマーの主分散 の活性化エネルギー $\Delta H_{\mathrm{a}}$ を求めた。

\section{6 熱分析}

グラフトフィルム中のコラーゲンの熱変性を, パーキ ンエルマー社製示差走查熱量計 (DSC) Pyris 1 により観 察した. 測定は, 試料 1 5 m と水 $20 \mu \mathrm{L}$ をアルミパ ンに入れて密閉し, 数十分保持した後昇温速度 $5^{\circ} \mathrm{C} / \mathrm{min}$ で行った。

\section{7 走查型需子顥微鏡 (SEM) 観察}

日本電子(株)製走查型電子顕微鏡を用いて，コラーゲ ン部分を酸分解除去したグラフトフィルムの表面を観察 した。酸分解は， $6 N$ 塩酸一水酢酸(1)を用いて室温で 行った。 ただし、 PHEMA は上記酸に溶解するため, ペプシンによりコラーゲンを分解した.

2.8 グラフトフィルムの水に対する膨潤とその引張 強度

グラフトフィルムを室温で蒸留水に 30 分間浸漬し, 浸漬前後の重量变化から膨潤率を算出した。

グラフトフィルムの膨潤時の引張強度は, 東洋精機 (株)製ストログラフ M-100を用いて測定した。
Table 2. Initiator-free photo-graft polymerization of various monomers onto solubilized collagen films

\begin{tabular}{lccc}
\hline \hline Monomer & $\begin{array}{c}\text { Irr. time } \\
\text { (h) }\end{array}$ & $\begin{array}{c}\text { Conc. } \\
\text { (mol/L) }\end{array}$ & $\begin{array}{c}\text { Grafting } \\
\text { (wt\%) }\end{array}$ \\
\hline BMA & 2 & 0.943 & 334 \\
& 3 & 0.943 & 388 \\
HEMA & 4 & 0.943 & 653 \\
& 2 & 0.943 & 312 \\
MMA & 3 & 0.943 & 568 \\
& 4 & 0.943 & 636 \\
St & 2 & 0.943 & 291 \\
& 3 & 0.943 & 442 \\
& 4 & 0.943 & 602 \\
& 2 & 0.943 & 80 \\
& 3 & 0.943 & 307 \\
& 4 & 0.943 & 350 \\
VAc & 5 & 0.943 & 285 \\
& 4 & 4.32 & 469 \\
\hline
\end{tabular}

Solvent, $\mathrm{MeOH}$. Solubilized collagen films, $40 \sim 70$ mg. Solution, $5.5 \mathrm{~mL}$. Temp., $20^{\circ} \mathrm{C}$.

\section{3 結果亡考案}

\subsection{MMA の無触蝶光グラフト重合における溶媒効 果}

Table 1 に種々の溶媒を用いたコラーゲンフィルムの 膨潤率と MMA の無触媒光グラフト重合の結果を示す. 用いたコラーゲンフィルムの厚さは約 $20 \mu \mathrm{m}$ 之薄いた め, 20 分で十分平衡に達していた。

MMAではコラーゲンフィルムはほとんど膨潤しない がメタノール、エタノールで顕著に膨潤し，膨潤率が高 くなるに従いグラフト率が上昇した。コラーゲンフィル ムがほとんど膨潤しない, アセトン，トルェン，MMA ではホモポリマーは生成するが，ほとんどグラフト重合 
種々のビニルモノマーの可溶化コラーゲンフィルムへの無触媒光グラフト重合とグラフトフィルムの物性

が起こらなかった．本方法でのグラフト重合では，溶媒 がグラフト率の高低を左右する大きな要素であると考え られる. 既報1)で用いたメタノールは, グラフト率を数 十加ら数百 $\mathrm{wt} \%$ までを，モノマー濃度や光照射時間を 変化させることにより容易に調製が可能な溶媒である.

\section{2 種々のモノマーの無触媒光グラフト重合}

メタノールを溶媒にして, MMA, BMA, HEMA, St, VAc 溶液を所定時間光照射したときのグラフト率を Table 2 に示す.

MMA, BMA, HEMA は照射時間が増加するとともに グラフト率も増加し，いずれも4時間でグラフト率が $600 \mathrm{wt} \%$ を超えた。 VAcはまったくグラフト重合せず, 溶液中にホモポリマーも観察されなかった。これは,こ のグラフト重合系では溶液中の溶存酸素を除去していな いため, 溶存酸素が VAcの重合を禁止したと考えられ る.

St は 2 時間の照射ではグラフト率が $80 \mathrm{wt} \%$ とほかよ り小さい值で,これは St の成長速度定数がほかのモ， マーに比べて小さいためだと考えられる.また，Stは 照射時間が 3 時間を超えてもそれ以上グラフト率の增加 は観察されず,さらに高グラフト率のフィルムを得るに はモノマー濃度を高くする必要があった。

\section{3 グラフトフィルムの FT-IR-ATR 測定}

既報”では, PMMA グラフトフィルムの A 面の表面 から $0.4 \mu \mathrm{m}$ 以上に元のコラーゲン層が保持されている ことを示した。 そこで, 同様にPMMAのほかに PBMA, PSt, PHEMA グラフトフィルムのA面の FTIR-ATR スペクトルを Fig. 1 に示す.

各グラフトフィルムのスペクトルには, それぞれのホ モポリマーに起因する吸収ピークは観察されず， $\mathbf{A}$ 面 は $0.4 \mu \mathrm{m}$ 以上のコラーゲン層が保持されていることが わかった。したがって、いずれのグラフトフィルムも医 用材料としての使用が可能であると考えられる.

また，Fig. 2 にはB面の FT-IR-ATR スペクトルを示 したが，いずれのグラフトフイルムにも各ポリマーの ピーク中にコラーゲンのアミドの吸収か観察されてい る. 前報)でも示したが B 面表面はコラーゲンがミクロ 相分離様の構造で存在し, ポリマーの疎水性マトリック スにコラーゲンが島状に点在していると考えられる。

3.4 グラフトポリマーの主分散の活性化エネルギー コラーゲンフィルム内に浸入したポリマー分子は, コ ラーゲン分子や同じポリマー分子からさまざまな束縛を 受け, PMMA グラフトフィルムの場合, PMMA の主 分散の活性化エネルギー $\Delta H_{\mathrm{a}}$ はグラフト率とともに大 きくなった2). まず, 種々のグラフトポリマーの主分散 の $\Delta H_{\mathrm{a}}$ を Fig. 3 に示す.

PHEMA, PMMA, PBMA にはェステル基, ヒドロキ シル基の水素結合を形成する置換基をもっている，これ

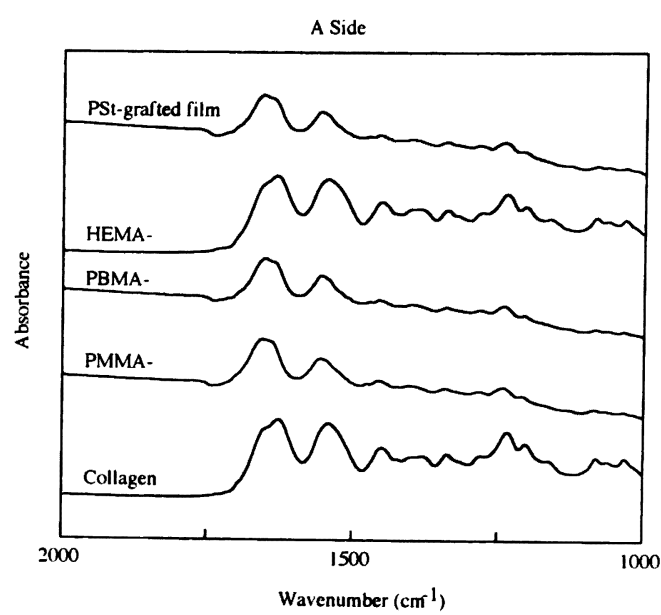

Fig. 1. FT-IR-ATR spectra of grafted films of $A$ side. ATR crystal is Ge. Grafting: PMMA, 602 wt\%; PBMA, 307 wt \%; PHEMA, 636 wt \%; PSt, $350 \mathrm{wt} \%$.

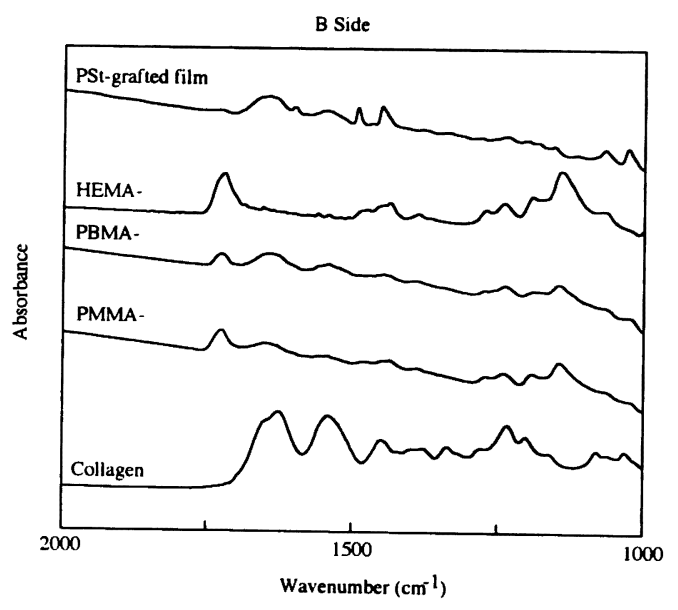

Fig. 2. FT-IR-ATR spectra of grafted films of $B$ side. ATR crystal is KRS-5. Grafting: PMMA, 602 wt \%; PBMA, 307 wt \%; PHEMA, 636 wt \%; PSt, $350 \mathrm{wt} \%$.

らのポリマーはコラーゲンに挿入されて物理的に分子鎖 が束縛されると同時にコラーゲン分子とも水素結合を形 成する. そのため, グラフト率が高くなると活性化ェネ ルギーが大きくなり, 特に, ヒドロキシル基をもってい る PHEMA グラフトフィルムの $\Delta H_{\mathrm{a}}$ は, 他のグラフト フィルムよりも大きな値となっている.

PStフィルムの $\Delta H_{\mathrm{a}}$ は $135 \mathrm{kcal} / \mathrm{mol}$ であるが, グラ フト率が高くなると徐々に減少し,グラフト率 469 wt\%で $85 \mathrm{kcal} / \mathrm{mol}$ になった. これは, PSt は疎水性ポ 


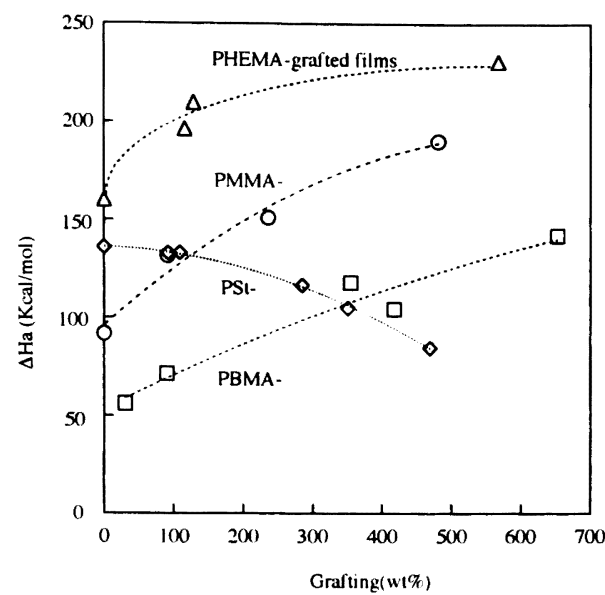

Fig. 3. Activation energy $\left(\Delta H_{\mathrm{a}}\right)$ of graft polymers in grafted films. $\Delta H_{\mathrm{a}}$ was estimated from the peak temperatures of dynamic loss modulus curves of grafted films at various frequencies.

リマーであるからコラーゲン分子とは水素結合を形成し ないこと，および PSt 分子鎖がコラーゲンマトリックス へ挿入されることにより PSt 分子鎖間の相互作用䐞く なるためであると考えられる.

\section{5 コラーゲンの熱変性}

動的粘弾性挙動はグラフトポリマーの主分散に着目し ているので, グラフトフィルム中のコラーゲンの状態を 直接示すものではない，そこで，グラフトフィルム中の コラーゲンの熱変性をDSC で観察することにより，コ ラーゲン分子の状態を考察した. コラーゲンの熱変性と は三重らせん構造がランダムコイルに転移することで, $30 \sim 40^{\circ} \mathrm{C}$ 付近に吸熱ピークとなって現れる. 皮革製造 工程でクロムなめしされたコラーゲンの熱変性温度は $100^{\circ} \mathrm{C}$ を超えることがある.

Fig. 4 には種々のグラフト率の PMMA, PHEMA, PSt グラフトフィルムの DSC 曲線を示す. いずれのグ ラフトフィルムも, 高グラフト率でコラーゲンの吸熱 ピークは高温側ヘシフトし, PMMA, PSt グラフトフィ ルムでは最終的に消失している，ピークの消失は，コ ラーゲンの熱変性は水が存在しないと起こらないことか ら，水分子と接触できるコラーゲン分子が咸少したこと が原因であると考えられる. PHEMA グラフトフィル ムの場合は，フィルムが水に非常によく膨潤するため高 グラフト率になっても吸熱ピークが明瞭に現れるが，グ ラフト率によるピークのシフト量は他のポリマーよりも 小さい.

PMMA グラフトフィルムでは, グラフト率 91, 151 $\mathrm{wt} \%$ のフルムの吸熱ピークはブロードで，ピーク幅 は $30^{\circ} \mathrm{C}$ から $70^{\circ} \mathrm{C}$ 付近までになっている. PMMA グラ
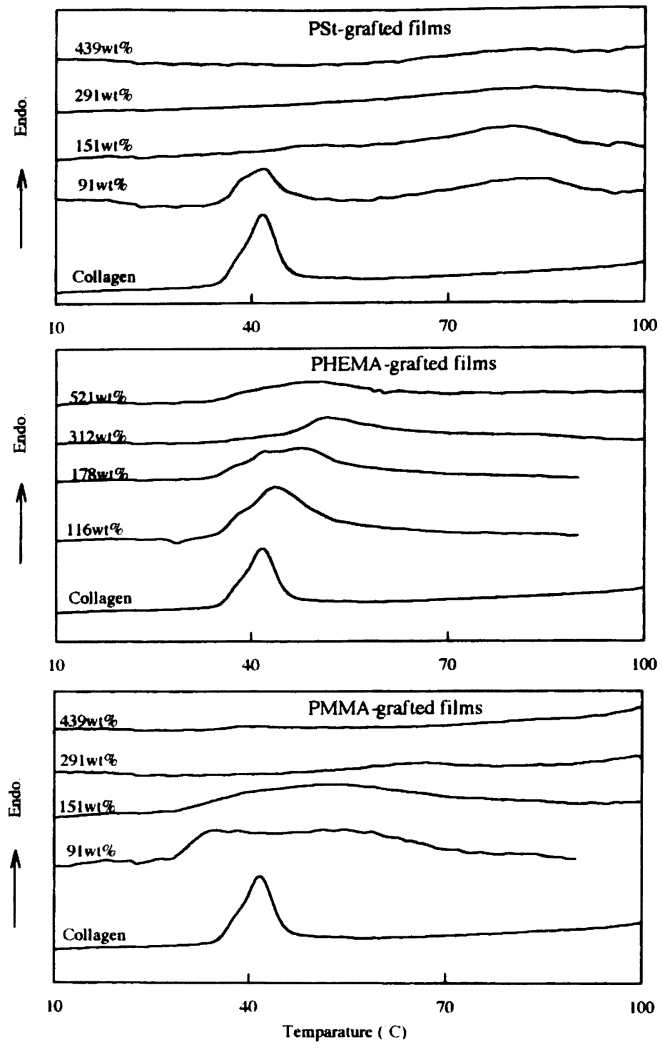

Fig. 4. DSC curves of grafted films. Each peak indicates the thermal denaturation of collagen in grafted films.

フトフィルムは前報2で示したとおり， B 面から A 面 近傍（A面のコラーゲン層の下層面）に向かって PMMA がパイル状に㨂入された構造であることから， PMMA は B 面加 A 面近傍に向加って連続的な濃度勾 配をもっている.ブロードな吸熱ピークはこのためであ ると考えられる.ここで, PBMAのDSCカーブは PMMA と類似していたため省略した.

一方, PSt グラフトフィルムの吸熱ピークは, グラフ 卜率 $92 \mathrm{wt} \%$ で二つのピークが観察された。一つは未修 飾のコラーゲン, もう一つはグラフトされたコラーゲン のピークと予想され, PMMA, PBMA グラフトフィル ムと違い, B 面から A 面近傍への連続的な構造ではな いことが示唆された。

\section{6 酸分解したグラフトフィルムの SEM 観察}

Fig. 5 にコラーゲンを除去した PMMA, PBMA, PSt, PHEMA グラフトフィルムのA 面と, B 面の SEM 写真 を示す。ここで，比較するポリマーのグラフト率は同程 度であるべきだが, PHEMAグラフトフィルムの場合 分解条件がマイルドな䣼素分解であるため, 高グラフト 
種々のビニルモ/マーの可溶化コラーゲンフィルムへの無触媒光グラフト重合とグラフトフィルムの物性
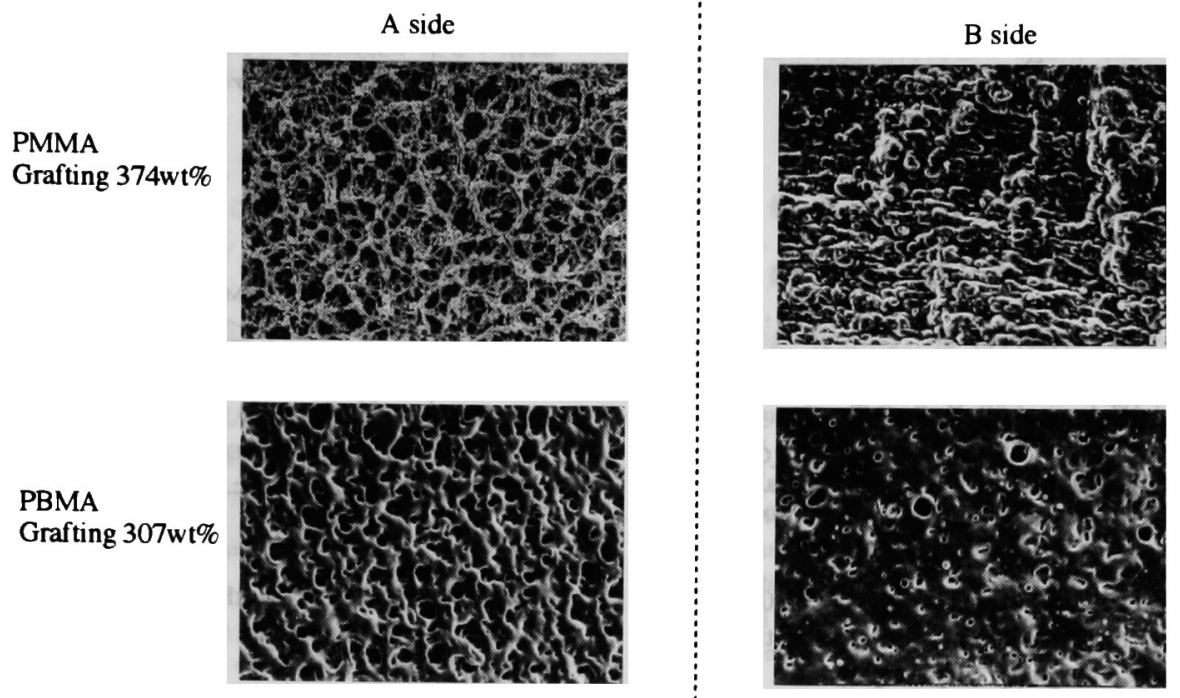

PHEMA

Grafting $129 \mathrm{wt} \%$
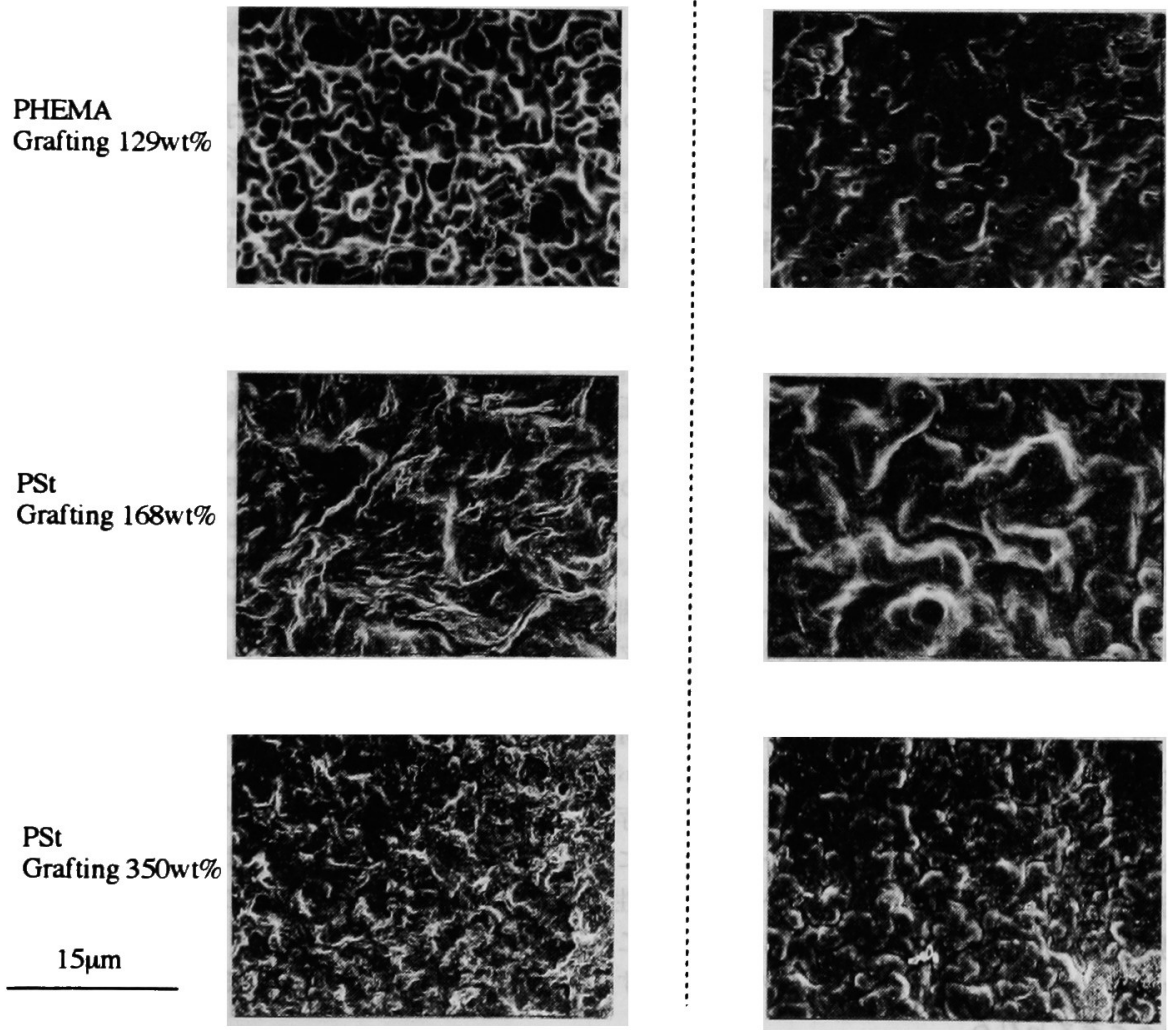

Fig. 5. SEM photographs of the surfaces of four polymers obtained from PMMA-, PBMA-, PHEMA-, and PSt-grafted films by removing collagen. 


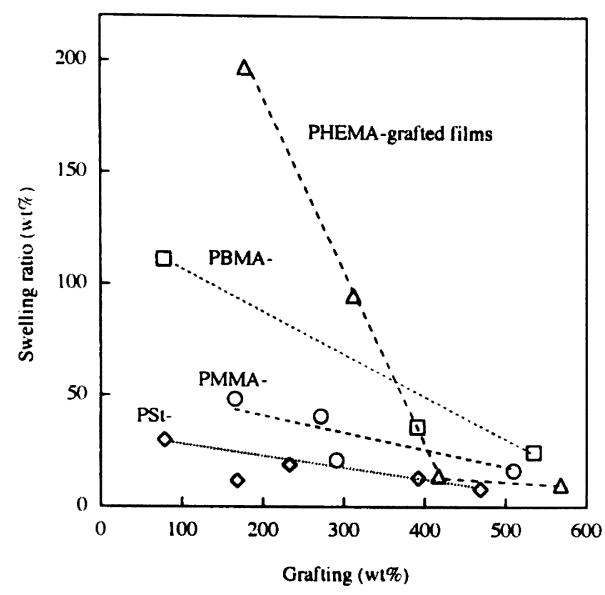

Fig. 6. Swelling ratio of grafted films $(30 \sim 50 \mathrm{mg})$ in water at room temperature. Swelling ratio $=[($ wet weight $)+($ dry weight $)] /($ dry weight $)$.

率のフィルムの分解には限界があり, やむを得ずグラフ 卜率 $129 \mathrm{wt} \%$ のフィルムを用いた。

A 面（表面を覆っていたコラーゲンを除去した表面） では PMMA, PBMA, PHEMA には多数の空孔が認め られるが，PStにはグラフト率の低い $168 \mathrm{wt} \%$ のィ ルムにさえ認められず, 他のグラフトフィルムとは構造 が違うことが示唆され, DSCの結果と一致した. PSt グラフトフィルムは, 光照射後 THFに 24 時間浸漬し たが,フィルムは多少膨潤する程度で溶解はしない，し たがって， SEM 写真では認められないが PStのアン カーの役目を果たす極微小のコラーゲンドメインは存在 する.

DSC, SEM 写真の結果から, PSt グラフトフィルムの 構造を次のように考えた. PSt 分子は蹯水性が強いため PMMA, PBMA, PHEMA のようにコラーゲンフィルム にパイル状に分散するのではなく，グラフト重合の先端 では PSt 分子が凝集してコラーゲン-PSt のよ゙ちらがマ トリックスともいえない状態でグラフト重合が進む，そ のとき，A面ではPSt はパイル状ではないため, SEM 写真で観察されたように PSt グラフトフィルムは空孔が 見られず, 大きく波打つ（波のへこみにコラーゲンが存 在する).この状態では, PSt 分子はコラーゲン分子に 大きな圧迫を受けないため $\Delta H_{\mathrm{a}}$ はグラフト率に相関性 がないと考えられる.また，DSCの二つのピークはこ の大きなコラーゲンのドメイン/マトリックスが存在す るためであると考えられる.

\section{7 グラフトフィルムの水に対する膨潤と湿閏引張 強度}

十分な湿潤強度は，医用材料として使用する際には必 要な要素であり, 本研究の主題でもある. Fig. 6 に

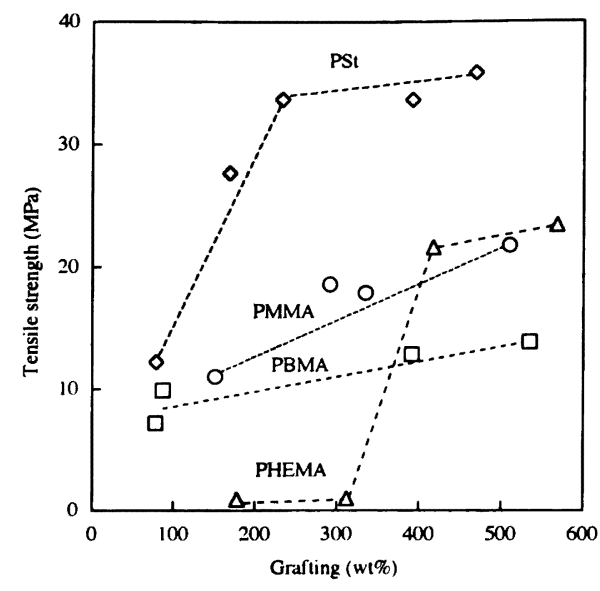

Fig. 7. Tensile strength of swollen grafted films. Swelling conditions are the same as in Fig. 6.

PMMA, PSt, PBMA, PHEMA の膨潤率を, Fig. 7 には そのときの引張強度を示す.ここで, グラフトフィルム の厚さは 40 200 $\mu \mathrm{m}$ と薄いので, 浸漬時間 30 分で平 衡に達していた。

膨潤率は, 親水性高分子である PHEMA で高いが, グラフト率が高くなると膨潤率は急激に低下し，グラフ 卜率が $400 \mathrm{wt} \%$ を超えると疎水性高分子の PSt グラフ トフィルムと同程度まで低下した．Fig. 3 で示したよう に PHEMA グラフトフィルムの $\Delta H_{\mathrm{a}}$ は他のグラフト フィルムよりも大きいことから, PHEMA 分子鎖は PHEMA 分子鎖どうしやコラーゲン分子と水素結合的 あるいは物理的に強固に絡み合っていることが予想さ れ, このために急激に吸水能が低下したと考えられる. この絡み合いは低膨潤率では解消されないため,このと きの引張強度は大きい値となっている。

最も疎水性高分子である PSt はコラーゲンの吸水力を 阻害するため低グラフト率でも膨潤率は小さく, 引張強 度も他のグラフトフィルムに比べ大きい. PBMA グラ フトフィルムはPMMA グラフトフィルムに比べわずか に膨潤能が高く、それに伴い引張強度も低くなってい る. コラーゲンフィルムをグルタルアルデヒドで架橋し たフィルムの湿潤強度は約 $10 \mathrm{MPa}$ であったので, 特に PSt グラフトフィルムでは, 大幅に強度を高めることが できた。 また，乾燥状態の PSt グラフトフィルムは硬い が, 湿潤状態では柔軟で，物理的に十分医用材料として 使用可能であると思われる.

\section{4 結 論}

種々のモノマー, 溶媒を用いて無触媒光グラフト重合 法により可溶化コラーゲングラフトフィルムを調製し， グラフト重合挙動, 各グラフトフィルムの構造と物理的 
種々のビニルモノマーの可溶化コラーゲンフィルムへの無触媒光グラフト重合とグラフトフィルムの物性

性質について以下のことが明らかとなった.

1) コラーゲンフィルムに対する膨潤能が大きい溶媒 ほど，同一条件ではグラフト重合率が高い傾向であっ た.

2) MMA以外にも BMA, HEMA, St をコラーゲン フィルムにグラフト重合することができた。成長速度定 数の小さいSt では，他のモノマーよりグラフト重合速 度が小さかった。

3) いずれのモノマーを用いたグラフトフィルムで あ，A面はコラーゲン層が保持されていた.

4) PMMA と同様に PBMA, PHEMA グラフトフィ ルムは前報2で示したような，ポリマーがコラーゲン フィルムにパイル状に打ち込まれた構造であることが示 唆されたが, PSt グラフトフィルムは PSt がコラーゲン フィルムに細かく分散せずに，ある程度凝集した状態で 存在すると考えられた.

5) 湿潤強度はグラフトフィルムの膨潤率と反比例的 な傾向であった．グラフト率が 100 wt\%を超えれば, PMMA, PBMA, PSt グラフトフィルムにおいて架橋コ ラーゲンフィルムより湿潤強度が高くなった。 また, PHEMA グラフトフィルムでも高グラフト率であれば
湿潤強度を高めることができ，いずれのグラフトフィル ムにおいても十分医用材料として使用可能であると思わ れる.

\section{文献}

1) 原田 修，杉田正見，山本統平，高分子論文集， 50, 471 (1993).

2) 原田 修，杉田正見，山本統平，三軒齋，高分子論文 集, 51, 710 (1994).

3) 宮田暉夫, 皮革化学, 28, 75 (1982).

4) P. R. Chatterji, J. Appl. Polym. Sci., 40, 401 (1990).

5) B. Ramaraj and G. Radhakrishnan, J. Appl. Polym. Sci., 52, 837 (1994).

6) J. T. Ma, L. R. Lui, X. J. Yang, and K. D. Yao, J. Appl. Polym. Sci., 56, 73 (1995).

7) P. Giusti, L. Lazzeri, S. D. Petris, M. Palla, and M. G. Cascone, Biomaterials, 15, 1229 (1994).

8) B. Sarti and M. Scandola, Biomaterials, 16, 785 (1995).

9) V. Shenoy and J. Rosenblatt, Macromolecules, 28, 8751 (1995).

10）井出文雄, “グラフト重合とその応用”, 高分子刊行会, 京都 (1987), p. 160.

Initiator-Free Photo-Graft Polymerizations of Various Vinyl Monomers onto Solubilized Collagen Films and Characterization of Grafted Films

Osamu HaRADA*1, Kazushige Kadota*1, and Tohei Yamamoto*2

*1 Hyogo Prefectural Institute of Industrial Research (Nozato, Himeji, 670-0811 Japan)

*2 Faculty of Engineering, Himeji Institute of Technology (Shosha, Himeji, 671-2201 Japan)

A marked solvent effect on initiator-free photo-graft polymerization of methyl methacrylate (MMA) was observed and the order of solvent to increase grafting was the same order of swelling of collagen; this was methanol $>$ ethanol $>$ $n$-propanol $>$ acetone $=$ toluene. Hence the polymerizations of $n$-butyl methacrylate (BMA), 2-hydroxyl ethyl methacrylate (HEMA), styrene (St), and vinyl acetate (VAc) were carried out in methanol. Good yields of graft polymers of respective monomers were obtained, except for VAc. By removing collagen with acid from grafted films, polymer films of the respective monomers were obtained. The surfaces observed by SEM photographs showed porous structure, except for poly(St). Viscoelastic properties of the grafted films and the SEM photographs indicated that the respective polymers dispersed finely in collagen. One of the surfaces was not grafted up to $0.4 \mu \mathrm{m}$, but it could keep enough wet-strength. The grafted films were expected as good biocompatible materials.

KEY WORDS Solubilized Collagen Film / Photo-Graft Polymerization / Initiator-Free / Biocompatible Material / High Wet-Strength /

(Received December 21, 1998: Accepted February 8, 1999)

[Kobunshi Ronbunshu, 56(5), 307-313 (1999)] 